\title{
Seismic characterization of a massive Peruvian landslide in the Colca river valley (Achoma, Arequipa)
}

\author{
Cristobal Condori ${ }^{1}$, Edú Taipe ${ }^{2}$, Orlando Macedo ${ }^{1}$, Yawar Hussain $^{3}$, Rosa Anccasi², Hans Balder-Havenith ${ }^{3}$, \\ George S. França ${ }^{4}$
}

${ }^{1}$ Departamento de Geología y Geofísica, Universidad Nacional de San Agustín de Arequipa, Arequipa, Perú

${ }^{2}$ Instituto Geológico, Minero y Metalúrgico - INGEMMET, Arequipa, Peru

${ }^{3}$ Georisk \& Environment, Liège University, Liège, Belgium

${ }^{4}$ Instituto de Geociências, Universidade de Brasília, Brasília, Brazil

Copyright 2021, SBGf - Sociedade Brasileira de Geofísica.

This paper was prepared for presentation during the $17^{\text {th }}$ International Congress of the Brazilian Geophysical Society held in Rio de Janeiro, Brazil, $16-19$ August 2021.

Contents of this paper were reviewed by the Technical Committee of the $17^{\text {th }}$ International Congress of the Brazilian Geophysical Society and do not necessarily represent any position of the SBGf, its officers or members. Electronic reproduction or storage of any part of this paper for commercial purposes without the written consent of the Brazilian Geophysical Society is prohibited.

\begin{abstract}
Volcanic-triggered landslides, floods, and earthquakes, are the commonly occurring natural hazards in southern Peru. The remote characterization of such events is crucial. Therefore, in the present study, seismic characterization of a huge landslide at Achoma Peru (71'41'19.55"O, $\left.15^{\circ} 39^{\prime} 40.01^{\prime \prime S}\right)$ in the valley of the Colca river are presented. The landslide occurred on 18th of June 2020 at 6:30 in the morning. There were no reported casualties, however, it affected many tourist places and agricultural areas in the Colca river valley. The landslide blocked the river resulted in the accumulation of water upstream (lake formation), about 2 million cubic meters of water was accumulated in a day. In this study, we analyzed the seismic energies produced by the landslide event. We examined seismological data recorded at five broadband seismic stations installed near the event site by the Volcano Observatory of the Instituto Geológico Minero y Metalúrgico (OVI-INGEMMET). Data were recorded in continuous mode at a sampling rate of 100 SPS in up-down, north-south, and east-west directions. In the first stage of data processing, data were saved in units of velocity after removing the instrumental response. Then data were demeaned, detrended and bandpass filtered. The signal envelope and spectrogram were calculated. In addition to the traditional approaches, the S-transformation was also used for the clear representation of spectral contents of the signals. Results show the clear detection of landslide event over all seismometers on both envelopes and spectrograms. The main energies are found concentrated over a frequency band of 1 to $10 \mathrm{~Hz}$. It is interesting to note that some small energy post-landslide events were also observed over the spectrogram. The s-transformation has increased the signal-to-noise ratio and different signal typologies are enhanced. It is concluded that the delineation and characterization of the main landslide collapse as well as other post-collapsed small energy events, are possible using remotely recorded seismic signals. The analysis of possible triggering influence of the continuous seismicity originated nearby by the AmpatoSabancaya volcanic complex are the future directions of this study.
\end{abstract}

Keywords: Spectrogram; S-transformation; Envelope; Landslide 